\title{
Gender in Literature. Women's Position from traditional to modern society
}

\author{
Género en la literatura. La posición de mujer en la literatura \\ desde la sociedad tradicional hasta la moderna
}

\section{Gènere en la literatura. La posició de dona en la literatura des de la societat tradicional fins la moderna}

\author{
Theodora Menti National and Kapodistrian University of Athens, Greece. \\ tmenti@phil.uoa.gr. \\ https://orcid.org/0000-0003-3100-5659
}

\author{
Christina Sideri.Model Lyceum of Anavryta, Greece.chrsid@phil.uoa.gr. \\ https://orcid.org/0000-0001-9526-0080
}

\begin{abstract}
The remarkable influence of gender studies in recent years on the Greek educational system has inevitably led to the integration of a multi-focal thematic section entitled "Gender in Literature" in the new Lyceum curriculum. This section truly captures the interest of adolescents, as it stimulates the approach of literary texts and promotes constructive discussions that often lead to further enjoyment of reading. On this base a collaboration between University of Athens and Anavryta Model Lyceum was carried out in Literature class in both institutions. This article aims to present the main stages of this cooperation on the subject of "Literary Representations of Women's roles from traditional to modern society", as the institutional framework for teaching literature clearly supports the historicity of texts. Besides explaining the rationale behind this educational action, we are proposing a selection of literary texts that were used in class and presenting the objectives and didactic methods practiced, the type of tasks assigned to the pupils as well as the skills developed by them. The paper insists on certain texts that are particularly valuable for this approach and offers examples of taking advantage of contextual elements. Finally, we are showing how this collaboration became a real example of extroversion for both institutions and we are attempting a comprehensive evaluation of this project and its impact within the students' and teachers' community.
\end{abstract}

Key words: gender in literature, woman's position, literary education, female writers.

\section{Resumen}

La notable influencia de los estudios de género en los últimos años en el sistema educativo griego ha llevado inevitablemente a la integración de un apartado temátic multifocal titulado "Género en la literatura" en el nuevo plan de estudios de la Educación Secundaria. Este apartado capta, de hecho, 
el interés de los adolescentes ya que estimula el acercamiento a los textos literarios y promueve discusiones constructivas que a menudo conducen a un mayor disfrute de la lectura. Sobre esta base, se llevó a cabo una colaboración entre la Universidad de Atenas y el Liceo Modelo de Anavryta en el marco de la asignatura de Literatura en ambas instituciones. El objetivo de este artículo es presentar los puntos básicos de esta cooperación cuyo eje temático era "Representaciones literarias de los roles de la mujer en la literatura desde la sociedad tradicional hasta la moderna", puesto que el marco institucional para la enseñanza de la literatura respalda claramente la historicidad de los textos. Además de explicar los fundamentos de esta acción educativa, se propone una selección de textos literarios utilizados en clase y se presentan los objetivos y los métodos didácticos puestos en práctica, el tipo de tareas asignadas al alumnado, así como las habilidades desarrolladas por ellos. En este artículo, se insiste en ciertos textos que son particularmente valiosos para el enfoque y se ofrecen ejemplos de cómo se saca provecho a los elementos contextuales. Finalmente, después de presentar cómo esta colaboración se convirtió en un ejemplo de extroversión para ambas instituciones, se aporta una evaluación integral de este proyecto y su impacto dentro de la comunidad de alumnado y profesorado.

Palabras clave: género en la literatura, posición de la mujer, educación literaria, escritoras.

\section{Resum}

La notable influència dels estudis de gènere als últims anys al sistema educatiu grec ha dut inevitablement a la integració d'un apartat temàtic multifocal nomenat "Gènere en la literatura" en el nou pla d'estudis de l'Educació Secundària. Aquest apartat capta, de fet, l'interés dels adolescents ja que estimula l'acostament als textos literaris i promou discussions constructives que sovint condueixen a un major gaudi de la lectura. Sobre aquesta base, es va dur a terme una col·laboració entre la Universitat d'Atenes i el Liceu Model d'Anavryta en el marc de l'assignatura de Literatura en ambdues institucions. L'objectiu d'aquest article és presentar els punts bàsics d'aquesta cooperació l'eix temàtic de la qual era "Representacions literàries dels rols de la dona en la literatura des de la societat tradicional fins la moderna", donat que el marc institucional per a l'ensenyament de la literatura dona suport clarament a la historicitat dels textos. A més d'explicar els fonaments d'aquesta acció educativa, es proposa una selecció de textos literaris utilitzats a classe i es presenten els objectius i els mètodes didàctics posats en pràctica, el tipus de tasques assignades a l'alumnat, a més de les habilitats que aquests desenvolupen. En aquest article, s'insisteix en certs textos que són particularment valuosos per a l'enfocament i s'ofereixen exemples de com es trau profit dels elements contextuals. Finalment, després de presentar com aquesta col-laboració va esdevenir un exemple d'extroversió per a totes dues institucions, s'aporta una avaluació integral d'aquest projecte i el seu impacte dins de la comunitat d'alumnat i professorat.

Paraules clau: gènere en la literatura, posició de la dona, educació literària, escriptores 


\section{Introduction}

The development of gender studies in recent decades has inevitably influenced the study of literature in the new Lyceum curriculum. This obviously brings the focus on the evolution of representations of biological and social sexes in Modern Greek literature (Apostolidou, 2002), as well as on the examination of identity and diversity issues through the lens of contemporary values and attitudes. Literature should thus be considered as a vehicle to support interdisciplinarity (biology) and social anthropology (gendered behaviour, social construction of the sex) in classroom (Athanasiou, 2009). Gender issues pose a number of objective questions that are openly raised during the educative procedures, encouraging subjective searches and promoting reflection in literature class: What is gender? What do we mean by literary representations of gender? In what ways are these two concepts related in the field of a literary text (Evans, 2004; Sifaki, 2015)?

2. The criteria for the selection of the section "Gender in Literature" in the new Lyceum curriculum

According to the new curriculum, the study of the thematic section "Gender in Literature" during the first term of the first year of high school, was selected on the basis of the pupils' age and literary interests, as they are going through adolescence, a most critical stage of selfdetermination, with the interest in the other sex maturing and being reinforced. Specifically, according to the institutional frnbamework the main criterion for selecting this subject is the fact that gender identification is a central issue for much of the Greek literary production in general and also for not few of the literary texts anthologised in the school books, including poetry and prose. Most importantly though, gender identification is a timely topic for teenagers who shape at this stage of their lives their own identity. The question of gender is related to the stage of adolescence in literary texts but also to the theme of love and it is always determined by the historical and social context as well as the perspective and style of each author. All the above offer the opportunity for a rich goal setting.

According to classroom educators, the section "Gender in Literature" is really a multi-focal subject that captures the interest of adolescents (Zacharatou, 2012). It stimulates the approach of literary texts and promotes constructive discussions that often lead to further enjoyment of reading. At the same time, the institutional framework for teaching literature in secondary education clearly supports the historicity of the texts, highlighting the era and conditions of both writing and reading. It is certainly important for students to understand that gender issues in literature concern all stages of human life and are related to many other topics, not only to blood 
relations (father-daughter, brother-sister, mother-son) but in fact to all areas of social life (friendship, love, marriage, family, economy, culture) (Mike, 2019). Although the school lesson does not ignore the literariness of texts (language, narrative techniques, aesthetic currents), it mainly focuses on gender representations, characters and roles, which are always defined by the historical, social and cultural context. Typically, texts depicting traditional societies have certain constants, as they reproduce social stereotypes, which is why their modifications and reversals are particularly important (Fisher et al., 2003). Similar images or findings are not readily offered in literary texts referring to modern society, where many volatile factors dominate such as complex social and cultural processes that tend to push individuals into particular gendered behaviours and roles (Kyriazis, 1995; Ziras, 1997; Diekman\& Murnen, 2004).

On this basis, students are asked to interpret the texts taking into account origins, time and ideology of the author or narrator, to compare perspectives or texts, to detect social stereotypes and to see how literary writing functions against these stereotypes. Besides, the ultimate goal of teaching in general, apart from providing basic knowledge and promoting social awareness, is to develop critical thinking and produce documented discourse that will be characterised by contemporary reflection, a broader insight and historical consciousness/empathy (Collins, 1993; Johnson, 2002; Kulhman \& Moutray, 2002; Gelder, 2005; Malafantis, 2006). To this end, only minor guidance is given by the teacher to the pupils, who work mainly on their own. The teacher encourages collaboration in groups where students study one or more texts, organize a rationale, freely present their views, learn from each other, learn to respect and embrace diversity, and last but not least shape a democratic conscience and a positive attitude towards life.

\section{Lyceum-University collaboration}

"Gender in Literature" instruction module, already tested in the Greek educational system for nine consecutive years, served as the basis for our Lyceum-University collaboration (cf. Menti, 2013). This collaboration commenced in the beginning of the school year 2019-2020 and evolved throughout the first term for secondary and winter semester for higher education. The action was based on the initiative of Dora Menti, tutor of Modern Greek Philology at University of Athens, and Christina Sideri, philologist of the Anavryta Model Lyceum, along with her colleagues -all teachers of literature at A Lyceum- taking part in this action. The selection of the literary texts, the main axis of the teaching and the overall organization of the project was carried out in the framework of the academic course "Approaches to the teaching of Modern Greek Literature" attended by fourth year students of the Department of Modern Greek. 


\subsection{Thematic axis and criteria for the selection of texts}

The thematic axis we chose was 'Women's Position in Literature' and the overall approach followed the historical evolution of things. It was based on a feminist perspective and aimed at depicting representative social roles and differences

The thematic axis we chose was 'Women's Position in Literature' and the overall approach followed the historical evolution of things. It was based on a feminist perspective and aimed at depicting representative social roles and differences between sexes, between sexes, avoiding the inclusion of texts with particular masculine violence or sexism (Ruthven, 1984; Eagleton, 1986/2003; Gamble, 2006; Moschovakou et al., 2019). It is true that, in our time, gender does not function as a separate field of study and ideological confrontation, but we rather perceive it as an element linked, inter alia, to social class, occupation, and nationality. Particular attention was paid to the coexistence of texts written by men and women writers, which contain illustrations and representations of the female sex (Pampouki, 1980; Athanasopoulos, 1997; Robinson 1997; Psarra, 2008; Roussou, 2010). The portrayal of women by the authors of both sexes particularly motivates students to trace differences or similarities in the representation of women by authors of the same or different gender (Fisher et al., 2003). The texts selected were addressed to all students of A Class of the Anavryta Model Lyceum for whom a two-hour weekly lesson is institutionally prescribed. In the selection of texts, apart from the thematic criteria, an attempt was made to include, in an evolutionary order, a variety of literary genres (folk song, narrative poem, theater, poem, autobiography, short story, novel):

POEMS

- П П $\alpha \alpha \lambda$

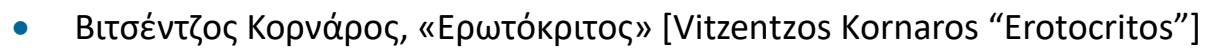

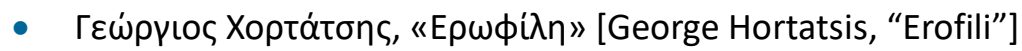

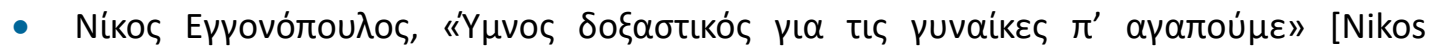
Engonopoulos, "Hymn to the glory of the women we love"]

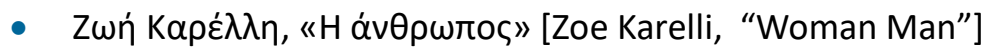

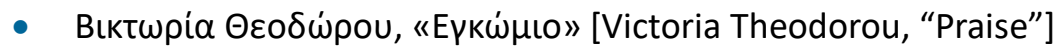

- Kıкń $\Delta \eta \mu o u \lambda \alpha ́$, «EKóvn» [Kiki Dimoula, "Dust"]

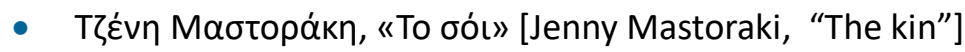


PROSE

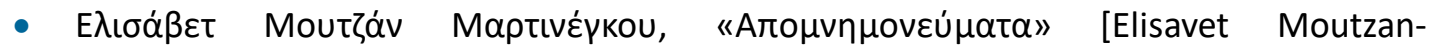
Martinengou, "My story"]

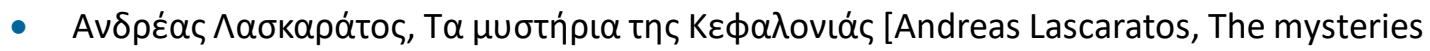
of Kefalonia]

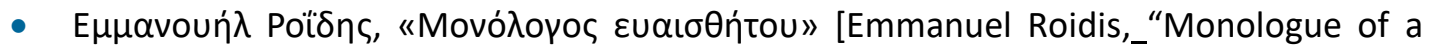
sensitive man"]

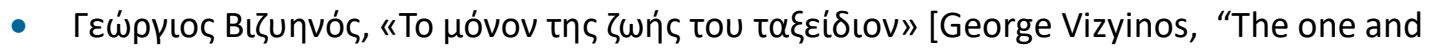
only journey of his life"]

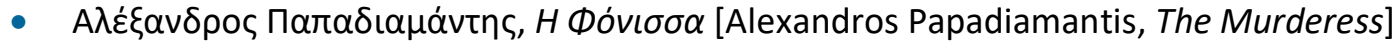

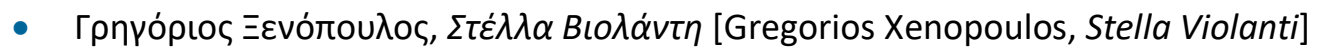


Theotokis, Honour and Money, "Face down" (short story)]

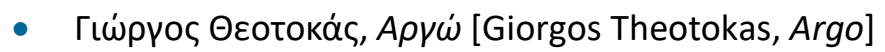

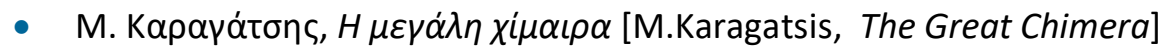

- $\Delta \mathrm{t} \delta \dot{\omega} \Sigma \omega t \eta \rho i o u, ~ M \alpha \tau \omega \mu \varepsilon ́ v \alpha \chi \omega ́ \mu \alpha \tau \alpha$ [Dido Sotiriou, Farewell Anatolia]

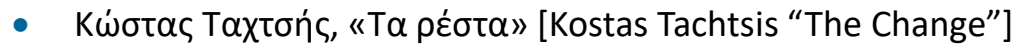

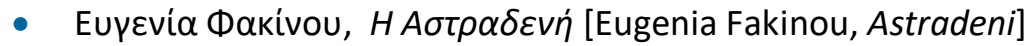

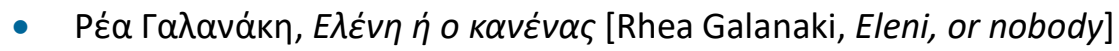

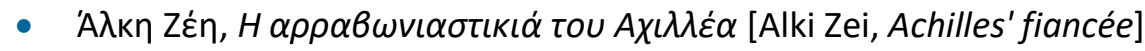

\subsection{Objectives-Methodology}

During our educational action students, working either in groups or individually and practicing ICT skills, were asked to identify through a comparative examination of texts how social perception of gender has been shaped over time, to link these perceptions with the historical and social context of the writer and also with different forms of art (cinema, painting, comics) as well as with their personal experience gained within their own environment. Particular emphasis was placed on women's social position, the stereotypes surrounding them, the antinomies and reversals we recognize around us from old times to the present day. These stereotypes stem largely from the patriarchal notion of "feminine nature" and are closely linked to the perpetuation of the human species through maternity and its identification with the virtues of patience, empathy and self-sacrifice. Our aim was to capture the stereotypes found in literary texts and investigate whether and how they survive in today's social life. In this context, the students were asked to: 
- Distinguish and describe central as well as minor literary characters, in relation to the social male or female roles, making the necessary references to the text. Justify their estimate taking into account the historical and social context in which the text was written.

- Express their opinion on the subject of the text, evaluate ideas, values, attitudes, behaviours that emerge from it. Compare these elements with current perceptions or relate them to personal experiences and emotions.

- Identify the narrator and focus of the text and justify the author's choice, taking into consideration the author's gender.

- Observe how the image of the sex is constructed (through the words and actions of persons, from what others expect from them, as well as from the extent to which persons accept or object to the role that they are assigned).

- Comment on social parameters that determine men's and women's attitudes (codes of conduct, needs, abilities).

- Compare the literary representations of the sexes with other performances from journalistic, scholarly discourse or multimodal texts.

- Practice creative writing and other forms of expression: change the storyteller to emphasise the importance of "voice", identify with the hero/heroine of the text and write pages of his/her diary or letters, turn an interactive scene into a narrative or vice versa, choose a literary description and depict it, provide their own ending to the story (Iser, 1978; Kalfas, 1994; Pesketzi, 1994; Jauss, 1995; Eagleton 1996; Souliotis 2012; Chontolidou, 2014).

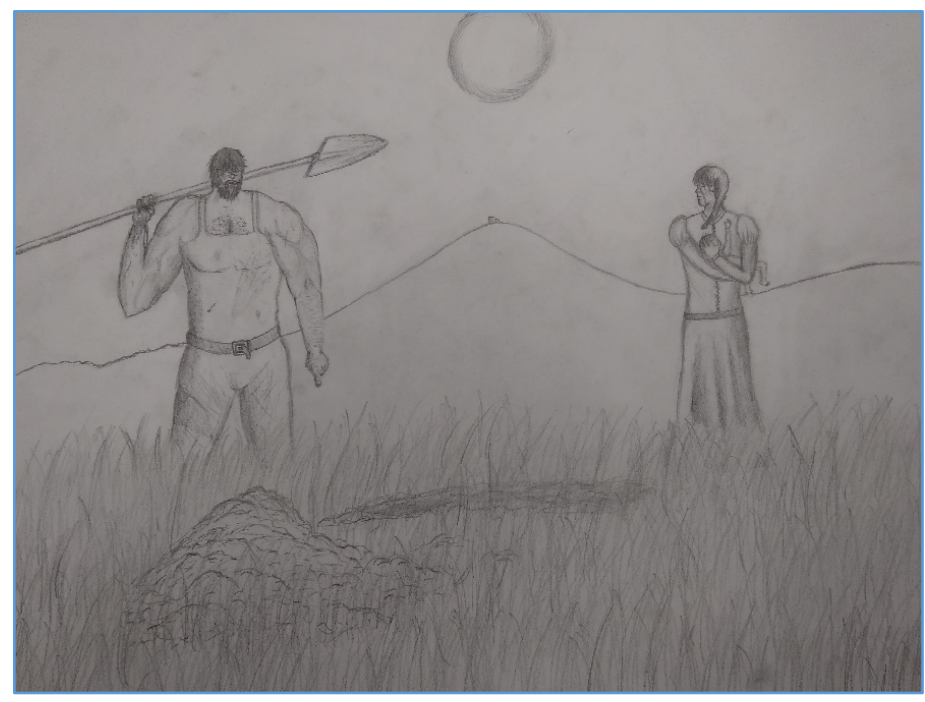

Figure 1. Konstantinos Theotokis, “Face down”. Student's creation. 


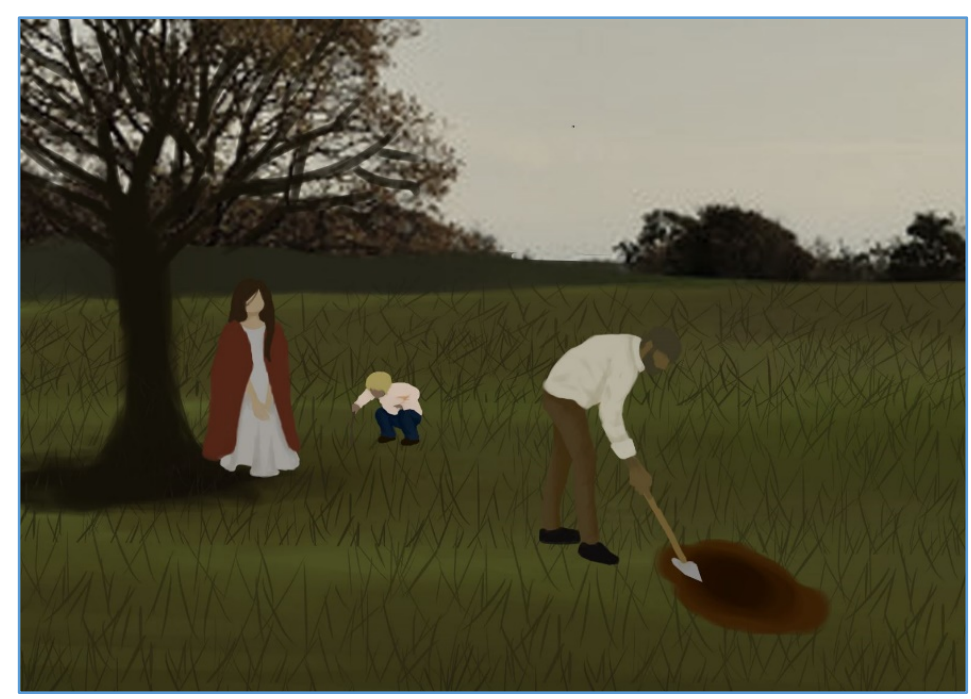

Figure 2. Konstantinos Theotokis, "Face down". Student's creation.

\subsection{Text utilization}

The proposed texts, particularly suitable for a feminist analysis, functioned more as a set of texts that gave teachers a common direction in approaching the position and the most prominent

The proposed texts, particularly suitable for a feminist analysis, functioned more as a set of texts that gave teachers a common direction in approaching the position and the most prominent womanly roles from traditional to modern society

womanly roles from traditional to modern society (Ruthven, 1984; Eagleton, 1986/2003; Gamble, 2006). On the one hand, a variety of texts highlight female devotion as a key feature of the gender (Mike, 2002; Karakotias, 2005; Mpasli, 2007), and, on the other, in several literary

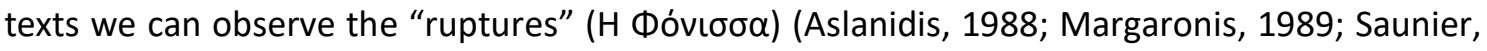

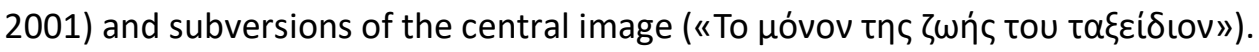

The Murderess is a scarcely 60 year old woman who decides to kill girls in order to set them free from a miserable life of servitude and release their parents from the heavy burden of the dowry. She conceives this insane idea, as she sits sleepless and tired next to her newborn granddaughter.

For many nights Frankoyannou had forced herself to keep her eyes open and had not allowed sleep to weigh down her eyelids, but had remained awake beside the little creature, which could have no conception of the trouble it was causing, nor of the suffering it would itself have to undergo if it survived. 
But see, nothing is what it seems, but is something different-more like its opposite.

Since sorrow is gladness and death is life and resurrection, then suffering is joy and sickness is health. In which case, all those scourges which appear to be so terrible and carry children off before their time, smallbox and scarlet fever and diphtheria and other illnesses, are they not in fact blessings, are they not caresses and woundings from the wings of the little Angels, who rejoice in heaven when they receive the infant souls? It is we human beings in our blindness, who think these are misfortunes, afflictions, something bad. [...] Shouldn't we like good Christians help the Angels in their task? Think how many boys, even noblemen's sons, are taken before their time. Even the daughters of the nobility die more easily -although it's rare for the sex- than the innumerable girls born into poverty. Girls of this class are the only ones with nine lives! It's as though more and more get born on purpose to put their parents through hell even in this world. When you think about it, it's enough to make you lose your mind...!

And her usual wish for small girls was for them 'not to live to get any bigger!'

'I have to say, sometimes you just feel like strangling them at birth...'

She may have said it, but of course she could never have done it. She herself didn't believe she could. ${ }^{1}$

On the other hand, in the story of Vizyinos, the divergence between sex and gender is manifested not only in the character of the narrator's grandfather but also in that of his depriving and authoritarian wife, Chrousi, who makes all the trips prepared by her husband and is compared to the most extreme version of the male sex, the janissaries (Athanasopoulos, 1996).

\begin{abstract}
I knew that no one ever crossed grandmother's threshold without being pressed into doing some chore or other. Nevertheless, after the way in which I had been summoned from Constantinople, and considering the purpose for which I had come, I expected to be informed what had become of poor grandfather in this struggle with the angel. So I stood there unwillingly holding the jugs and wondering how to broach the subject, after his wife's behaviour and the reception she had given me.

But grandmother was accustomed to seeing her orders obeyed instantly.

“Don't just stand there, you weakling! she shouted. “Don't just stand there! Are you afraid of straining your kidneys? And to think you want a shirt and collar from me. A curse on you, you good-for-nothing, you rascal, you lazybones!"
\end{abstract}

\footnotetext{
${ }^{1}$ Translation by Denise Harvey, 2011 (pp. 4, 34, 15); for the digital form of the Greek text see the

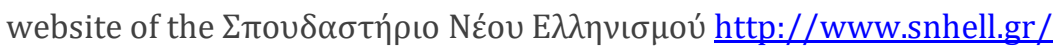


In such circumstances grandmother resembled those contraptions which, once wound up, must play their music to the last note. [The difference was just in this, that no one could stand listening to grandma's music till the end.]

"Where's grandpa, grandma? "I asked respectfully, having returned to find her in a better mood, probably because there was no other task at hand for me to perform.

"And well might you ask! " tuning herself to another key. "He's gone and left me! The layabout, the lazybones, the good-for-nothing, the ne'er-d-well! " and so on and so forth.

Grandmother -I thought to myself- must expect grandfather to come out of his tomb every morning to perform the tasks she assigned to him during his life, and to return to his grave in the evening!

"What do you expect poor grandpa to be doing now (that) there's no work to do?" I said in a low voice, as if talking to myself.

"Why, he's sunning himself!" retorted grandmother, winding herself up to an even higher pitch. " He's sunning his belly, the idler, the sponger, the laggard! " and so on and so forth.

How strange, I thought. She's keeping her eye on the poor man even in the next world to see what's he's up to.

Whenever grandfather (was) tired of grandmother's invective, he would sneak out and climb that steep rock and sit for hours up in the sunshine. Grandfather justified his choice of spot by asserting that as well as the warmth he enjoyed the charming panorama of the country from up there. Everyone knew, however, that grandfather used to climb so high because, owing to her rheumatism, it was the only place where grandmother could not come and fetch him home.

"All these years we've been married, I would make the preparations and she would make the journey. [...] There was one journey I was planning secretly, love. I was keeping it for myself. For years and years I put aside any little extra money and I hid it as best I could. When I'd saved 50.000 piastres, I made up my mind and called your grandmother-when I had my mind made up I didn't stand on ceremony with her. So I say to her with a decisive air 'Chrousi! I'm planning to go on a journey, so make sure there's no pregnant animal or sick man or anyone needing help, and make sure no visitor enters the house, otherwise, I'll smash his legs! "

Grandfather made a gesture which showed his admiration for what he had done. Then he went on. "You should have been there to see how flummoxed she was! She didn't say a word! That's just what I wanted. [..] When I had crossed myself ready to mount, I said to her: "'Come on, Chrousi, it's a matter of life and death! Forgive me and may 
God forgive you!' Whereupon she burst into tears". Grandfather spoke agitatedly, as if the scene were taking place at that very moment. [...]

"The tears in her eyes! "exclaimed grandfather, changing his tone." "What could I say? I lifted her on the horse and packed her off to the Holy Land with her brother.

"From then on," said grandfather, brushing the palms of his hands together as if he were dusting them, "I've never tried to make a journey. "

[...] So I was married with pomp and ceremony, and instead of being taken by some janissary I was taken by your grandmother."

Grandmother, with her hands clasped round her knees, her hopeless gaze fixed on the grandfather's face, sat by his side, pale and motionless as if she were turned to stone. What would the unfortunate woman not have given to prevent him from going on this journey! ${ }^{2}$

These texts were the basis for the transition from the original erotic model of women in the poems we have chosen (Tolika, 2006) to the existential search for a separate entity (Frantzi et al., 1990; Christou, 2016; Karageorgiou, 2019) through the articulation of the speech of «H

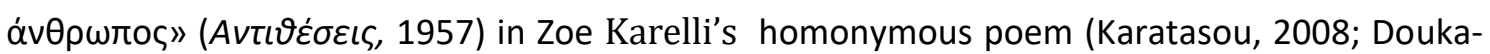
Kampitoglou, 2012).

\footnotetext{
I do not cry or sing,

but the break I must make

is the cruelest

to know the world through myself

to speak my own words.

I who until now have existed

to worship, respect and love.
}

I no longer belong to him,

I exist on my own,

a human being.

Zoe Karelli, 'Woman Man/E $\gamma \omega ́, \eta ~ \alpha ́ v \theta \rho \omega \pi o \varsigma^{\prime}$ (1957), translated by Karen Van Dyck (2009).

\footnotetext{
${ }^{2}$ Translation by Peter Mackridge, 2014 (pp. 37-39, 45-47, 49, 56); for the digital form of the Greek text

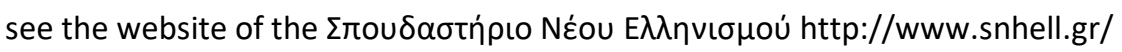


This discourse can then be deservedly intersected with Eleni's individual artistic claims in the homonymous novel by Rhea Galanaki. In her postmodern feminist work, Rhea Galanaki combines History with gender concerns and mythological context, as is the case with her novel Eleni or Nobody (Anagnostopoulou, 2011; Zerdeli, 2015; Gerakini, 2017; Marcou, 2018). This particular book is a biographical novel of the famous painter Eleni Boukoura- Altamura (Marcatou, 2009). The protagonist was born in Spetses in 1821 and was the eldest daughter of Arvanitis Captain and fighter Yannis Boukouras. From an early age, Eleni realises that she is different from the girls of her age and moves away from the predetermined social roles of her time. Her only allies will be her progressive father and her teacher Raffaelo Ceccoli, who encouraged her to broaden her artistic horizons.

The fact that what was for her a normal practice of going out and observing did not apply to the other girls led her to the conclusion that perhaps she was somewhat different from the other girls of her age, but also from the other women in her family. Eleni had to be punished, as she went on drawing not only in the breaks, but in class too, during the lessons.

Eleni did not give in to tears as long as the punishment lasted, the duration of which seemed longer and more unbearable because of the humiliation. It was then however, that she decided she would become a painter whatever happened, even if this meant always being different from other girls of her age and even from the other women in her family.[...] She swore on the faith of her mother tongue that only death would prevent her hand from painting, while her proud, and so eventually insubordinate mind wandered to her father's naval flag with its Greek words, 'Freedom or Death'.

By the time I'd reached twenty-seven, my mother had grown weary of trying to find a match for me. I could at least have consented to stay, to grow old as a spinster next to my married sisters and let the demons of painting turn my wits till the end of my life, as she said to me every day throughout the whole winter. But I wanted academies and laurels. Men's tokens. To do what with them, she asked. With my dowry, I could find a good match any time I wanted, she went on, ignoring the fact that I had agreed with my father to pay for my maintenance from the capital of that dowry for as long as I would remain in Italy for my studies.

In Italy, where she will continue her studies, Eleni disguises herself as a man, under the name of Giovanni Chryssini, in order to have the opportunity to study at the school of Nazarene painters in Rome. 
And I, resolving that morning in a foreign city to take examinations as a man, perhaps even to live like this for a few years, gave birth to myself as Nobody. The name with which I'd sign the exams, my studies and works was of no importance, given that the name Chryssinis, even Boukouras or Boukouris, when transliterated into Italian, gave no indication of whether it belonged to a man or a woman. I would live henceforth as Nobody.

The Nobody, who managed to escape from the Cyclops' cave, is the name by which Odysseus was introduced to Polyphemus.

During her stay in Italy, Eleni met and fell in love with an Italian painter, Saverio Altamura but their marriage did not last long. Saverio leaves her:

\begin{abstract}
In it (Saverio's letter) he told me that he'd left with Jane Hay, my English friend and a painter herself. [...] That he had taken with him our third child, Alexandros, who was still an infant, so that I wouldn't make him vanish too behind my Oriental veils. That he respected me as a painter, and that he had loved me as his wife, but that he had grown tired of my melancholic character, my lack of trust, my continuous trips, my displeasure whenever I had to dress in women's clothes, my shorn hair. That he would not be coming home. ${ }^{3}$
\end{abstract}

So, Eleni returns to her hometown of Spetses; she is now a recluse and reputedly a witch who dies all alone having burnt her paintings.

\title{
3.4 The exploitation of the context
}

The educational procedure presented above took frequently into account experience and information stemming from real life (e.g. daily news) as well as from movies (Aggeli, 2013; Georgiadou \& Mpikos, 2017). This helped us also expand the cultural field to another system of reference, including the lack of freedom of women which burdened and still burdens the gender across much of the globe. To this end, the French-American animation "Persepolis" (2007) by M. Satrapi and B. Parano, with the heroine of Margie growing up, as an exception, in a progressive family in Tehran in 1978 was projected and discussed in class. Due to the Iran-Iraq war and the prevalence of religious fanaticism Margie's parents send her to study in Vienna where, growing up and facing controversial identity issues, she discovers another dimension of her life and sex.

\footnotetext{
${ }^{3}$ Translation by David Conolly, 2003 (p. 21-22, 46, 53, 75-76).
} 
3.5 School visit at the Faculty of Philosophy and its Library and a university lesson in classroom

Indeed, the distance between the two cooperating educational institutions in Athens is large and often insurmountable. However, a visit for the Lyceum students was planned from the very beginning at the Faculty of Philosophy, as well as a guided tour in the Faculty Library and the attendance of an academic class. This visit took place on good terms in the middle of the first semester on Thursday 28th November 2019, its main theme being Alexandros Papadiamantis'

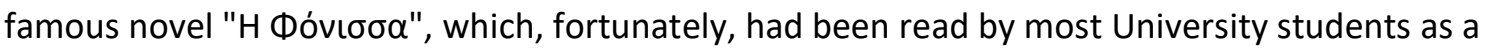
whole literary book at some point in their lives and by most Lyceum students in the 3rd High School. That is why our first meeting resulted in a dynamic reflection on the biological and social gender of the heroine, the way the author creates and treats her, the way each of us perceives her attitude and actions. After the visit at the university, the general analysis of the literary work, the focus on the heroine and the verdict on her actions, we set the next meeting towards the end of the semester so that we could move on to a different literary text that cancels stereotypes and predisposes to the position that women occupy nowadays. The questioning of the social gender that had been imposed on women by the family for centuries and the emergence of feminist consciousness by the new poets of the regime state period were the next and final stage of our cooperation. This was indeed a true example of extroversion and feedback for the university class. Our collaboration was certainly based on genuine contact and fruitful dialogue with students, enriching at the same time the quests of struggling secondary school colleagues.


information on the maternal model and outdated perceptions about upbringing and childcare, and is a representative sample of writing stemming from a younger generation which challenged social conventions and claimed more freedom (Van Dyck, 1998; Panagiotou, 2017):

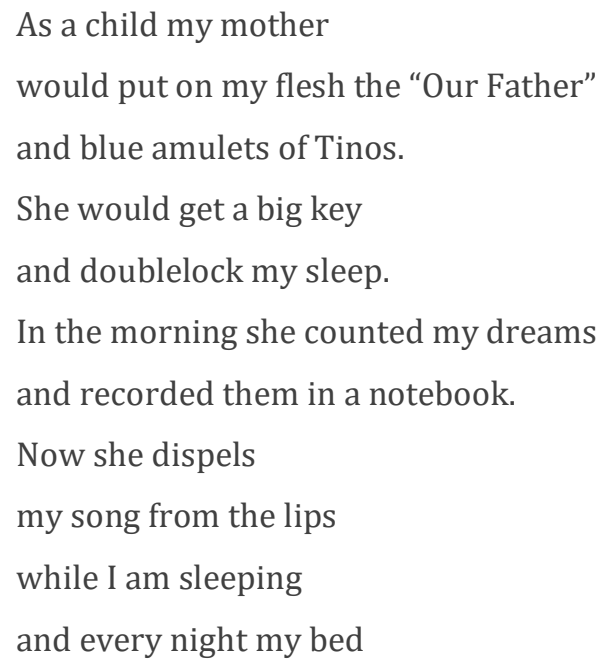


becomes an embroidered frame

with "Freedom or Death" written on it.

\section{Evaluation of the co-operation and dissemination of its results}

In an overall evaluation of our cooperation it would be appropriate to take into account the following criteria: students' response to the implementation of this educational action, the choice of texts and the communication and feedback. The students were very interested in the proposed texts and eagerly responded to all the tasks assigned to them; they composed an anthology with excerpts of texts they had come across and presentations of the female presence in them highlighting the evolution of the womanly position over time, whereas several of them drew inspiration from the texts and created remarkable works of art. A group of students went even further choosing to extend the study of certain literary pieces (e.g. Galanaki's Eleni, or Nobody) within the frame of another collaboration, this time with Lyceum Condorcet of Paris, exploring not only the gender quests of the authors but also the use of the ancient myth in Modern Greek literary texts.

In her direct contact with the high school students, the University teacher realised that students who came across an excerpt of the Papadiamantis" “Фóvıøoa" had satisfactory knowledge about the story, the plot and the central heroine's character; they easily shaped her gender's social profile, integrated it into the historical context and focused on the multiple instances of its reversal within Frankoyannou's family, observing with ease the author's interactions between himself and the characters of his work. In particular, during the class they recognised elements about the birth, upbringing, livelihood, marriage and dowry of women -important sub-topic of the novel-, and expressed their views on both the actions of the killer and the author's reasoning. The students noticed the insignificant role of the male figures in the novel and highlighted the social and other causes behind the murders committed by the heroine. They disagreed with the desperate attitude of this woman and most of them condemned her unconditionally, though there was a small minority of dissenters who were not given the opportunity to support and exchange views due to lack of time. At the second two-hour meeting at the Lyceum's auditorium on the $16^{\text {th }}$ January 2020 the students easily discerned the eternal suffocating motherly presence in Jenny Mastoraki's poem, compared it with their own personal experiences, and gave different versions about what would be the next stage in the relationship between mother and daughter. 
At the same time, the University students and most probably future high school teachers had the opportunity to attend a lesson where the theory already learned was implemented, which could be fruitful for their future career and aspirations.

Lastly, we would like to mention that after the presentation of our collaboration at the Symposium under the title "Approaches to Literature: Raising Awareness of Students in Creative Reading", organised by and held at Model Lyceum of Anavryta on the 1th February 2020, under the auspices of the University of Athens and the Institute of Educational Policy, we realised the wider impact that our project had on teachers; notably, an educational approach to the issue was set for May 18th at International School of Athens (Kifissia, Greece) $;{ }^{4}$ also, this presentation motivated the organization of a seminar for philologists entitled "From reading literary texts to promoting literacy" by the $2^{\text {nd }}$ Regional Center for Educational Planning of Athens ( $24^{\text {th }}$ February 2020, Nea Ionia) and of a literary competition under the title "We stay at home" by the $4^{\text {th }}$ Regional Center for Educational Planning of Athens (April 2020) addressed to students of secondary education.

In conclusion, despite the difficulties, the collaboration between the two institutions proved certainly successful regarding the quality of communication and the multifaceted use of the educational visits.

\section{References}

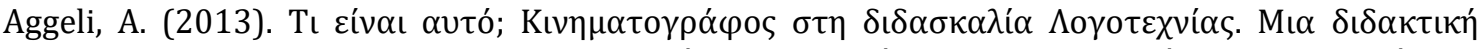

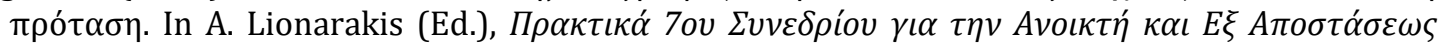

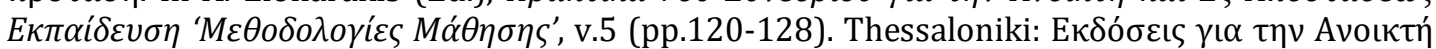



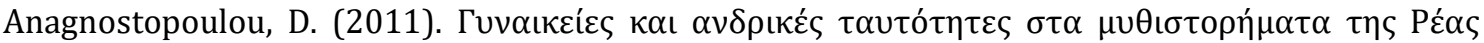

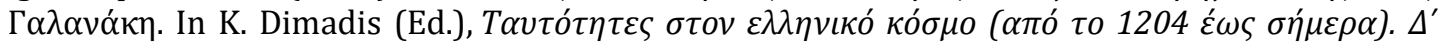

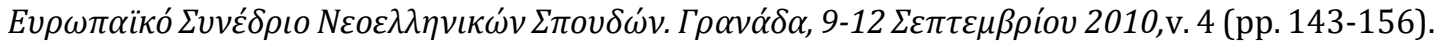

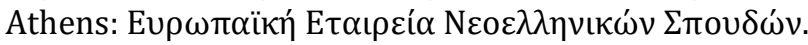

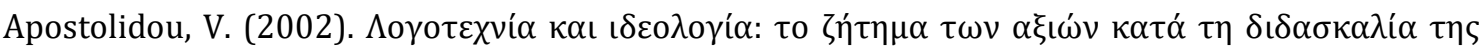

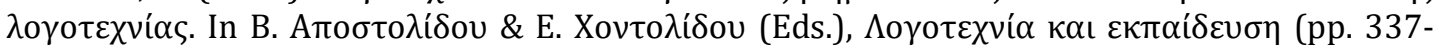

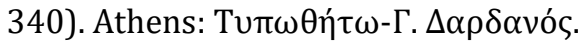

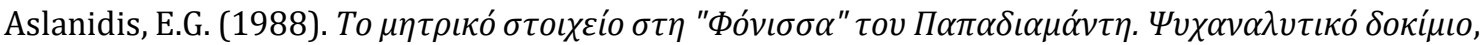
Athens: Pó́ $\pi \pi \alpha$.

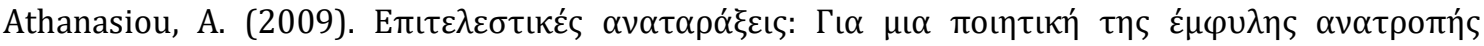


translated by G. Karambelas and edited by V. Kantsa (pp.217-227). Athens: A $\lambda \varepsilon \xi \alpha \dot{\alpha} v \delta \rho \varepsilon 1 \alpha$.

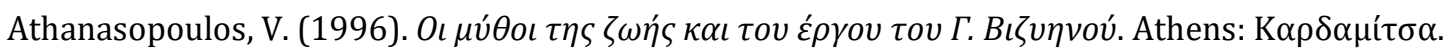

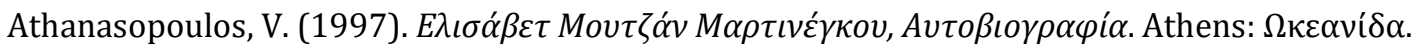

\footnotetext{
${ }^{4}$ This meeting had to be postponed due to the emergency circumstances created by the coronavirus pandemic.
} 


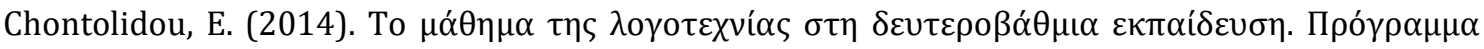

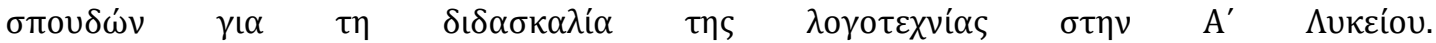
https://opencourses.auth.gr/modules/units/?course=0CRS160\&id=2878

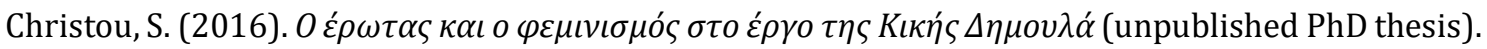
Ioannina. http://hdl.handle.net/10442/hedi/44166

Collins, N.D. (1993). Teaching critical reading through literature. ERIC Digest (ED 363 869).

Diekman, A.B. \& Murnen, S.K. (2004). Learning to be little women and little men: The inequitable gender equality of nonsexist children's literature. Sex Roles, 50, 373-385.

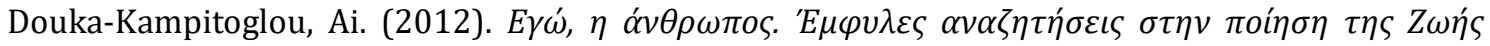

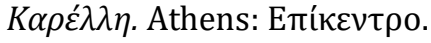

Eagleton, M. (1986/2003). Feminist Literary Theory. A Reader. New York: Blackwell.

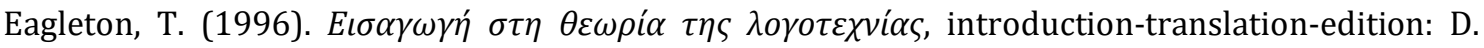

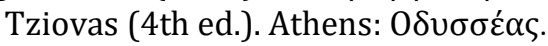

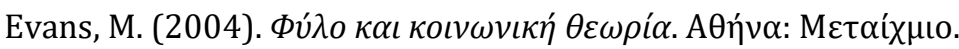

Fisher, J., Silber E.S., \& Sadker, D. (2003). Women in Literature. Reading Through the Lens of Gender. Westport, Connecticut-London: Greenwood Press.

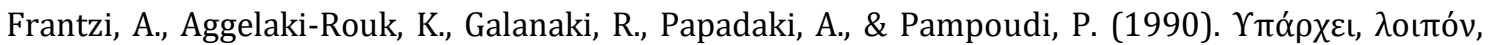

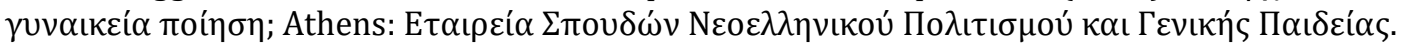

Gamble, S. (2006). The Routledge Companion to Feminism and Postfeminism. London \& New York: Routledge.

Gelder, T. (2005). Teaching critical thinking. College teaching, 53, 41-46.

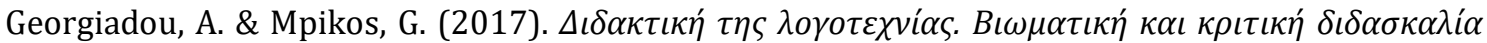

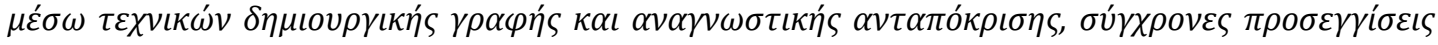

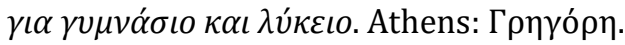

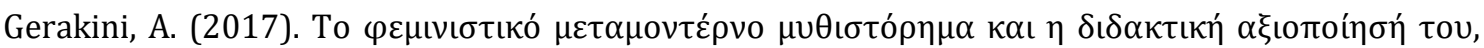

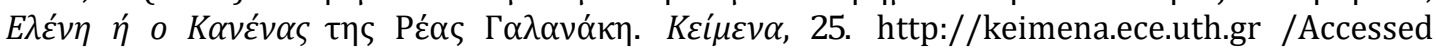
27.04.2020.

Iser, W. (1978). The Act of Reading: A Theory of Aesthetic Response. London: Routledge \& Kegan.

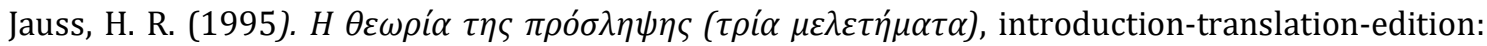

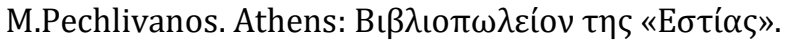

Johnson, C. (2002). Drama and metacognition. Early child development and care, 172, 203-221.

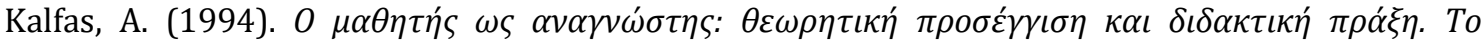

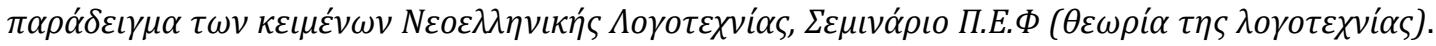
Athens.

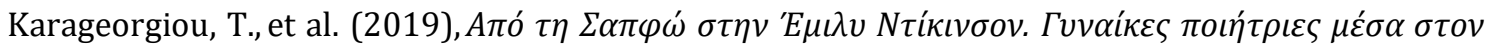

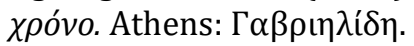

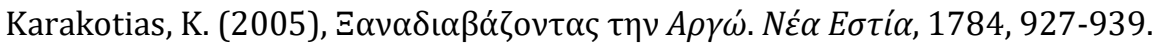

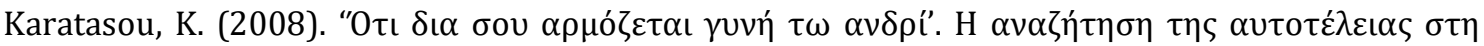

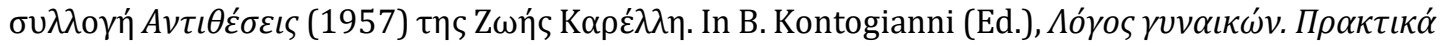

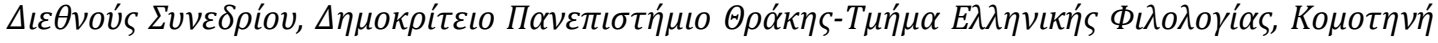
26-28 Maíov 2006 (pp. 199-211). Athens: E.L.I.A.

Kuhlman, W.D., \& Moutray, C.L. (2002). Dear author, your book is important to me. Reading Horizons, $43,115-125$. 
Kyriazis, N. (1995). Feminism and the State of Women in Greece. In D. Constas, \& Th.G. Stavrou (Ed.), Greece Prepares for the Twenty-First Century (pp.267-301). Baltimore: John Hopkins University Press.

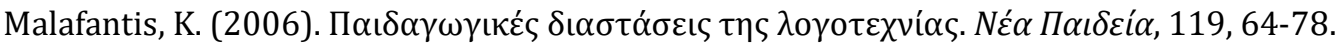

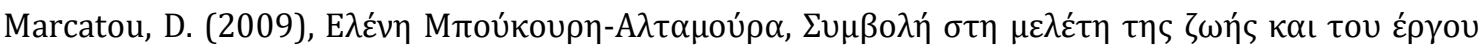

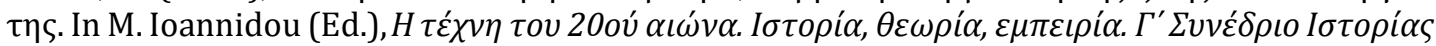

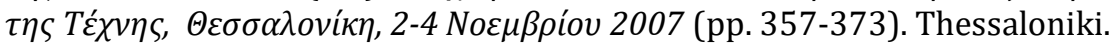

Marcou, L. (2018). La réception de l'Antiquité dans l'œuvre de la femme de lettres grecque Rhéa Galanaki, Anabases, 27, 27-38.

Margaronis, M. (1989). Alexandros Papadiamantis. Grand Street, 8, 2, 147-156.

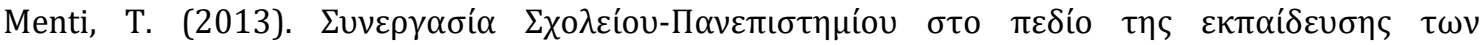

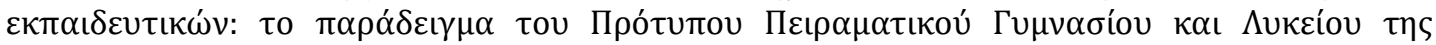





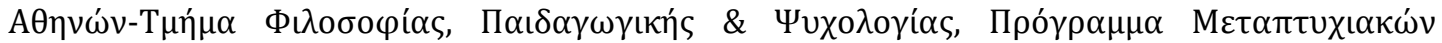





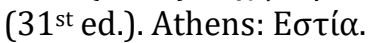

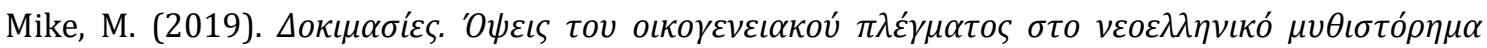
(1922-1974), Athens: Gutenberg.

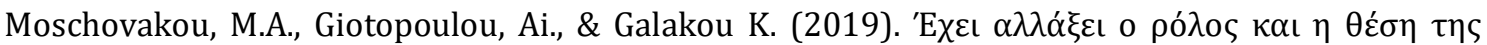



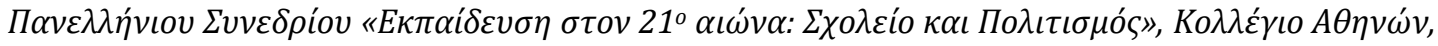

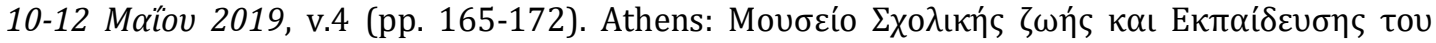
EKE $\Delta \mathrm{I} \Sigma Y$. https://www.academia.edu/41294364/

Mpasli, M. (2007). Silenced voices: female identity in Henry James and Gregorios Xenopoulos (unpublished PhD thesis). Thessaloniki. http://hdl.handle.net/10442/hedi/14601

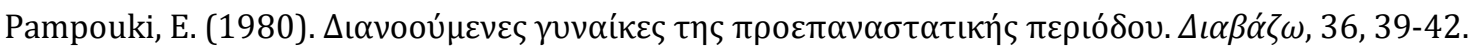

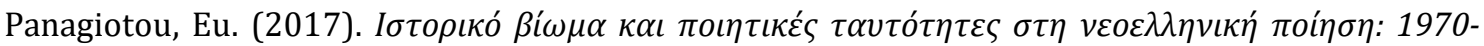

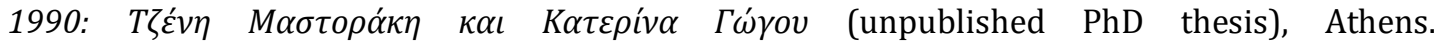
http://hdl.handle.net/10442/hedi/4075

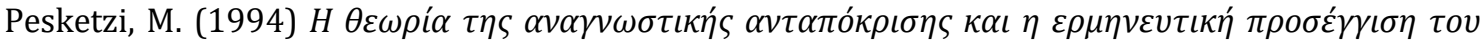

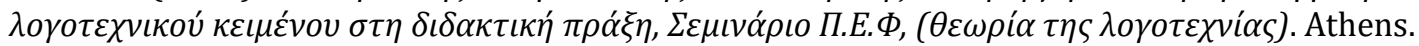

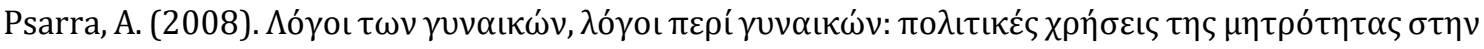

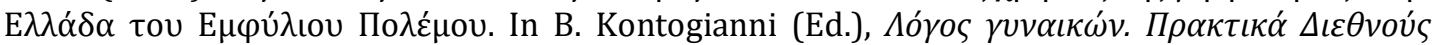

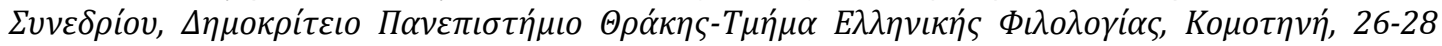
Maíov 2006 (pp. 657-667). Athens: E.L.I.A.

Robinson, C. (1997). Gender, Sexuality and Narration in Kostas Tachtsis: a reading of $T \alpha \rho \varepsilon ́ \tau \alpha$,

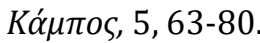



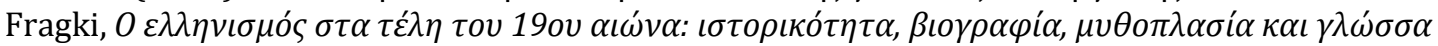

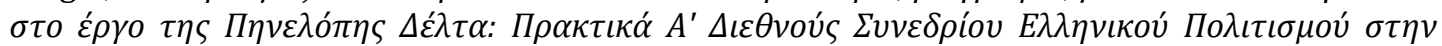

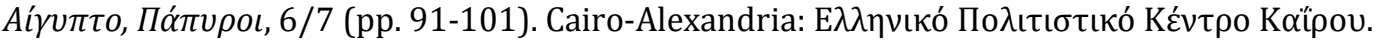

Ruthven, K.K. (1984), Feminist literary studies. An introduction. Cambridge-New York-Melbourne: Cambridge University Press.

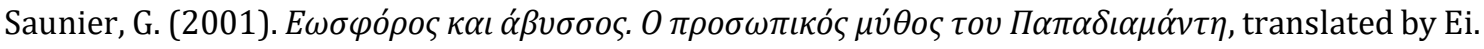
Tsolakelli. Athens: 'A $\gamma \rho \alpha$. 


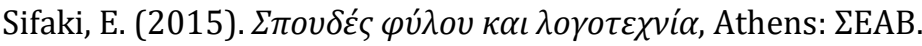

Souliotis, M. (2012)



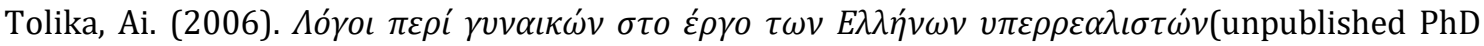
thesis). Thessaloniki. http://hdl.handle.net/10442/hedi/14526/Accessed 26.04.2020.

Van Dyck, K. (1998). Kassandra and the Censors. Greek Poetry since 1967. Ithaca, NY: Cornell University Press.

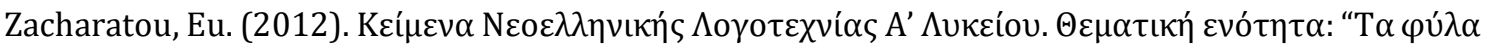

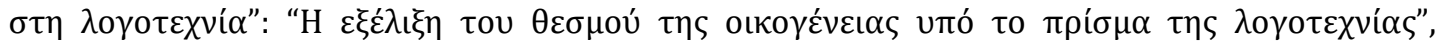

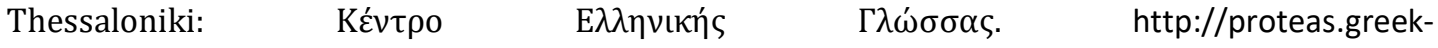
language.gr/files/document/arxeia/zaharatou_thesmos_oikogeneias.pdf/

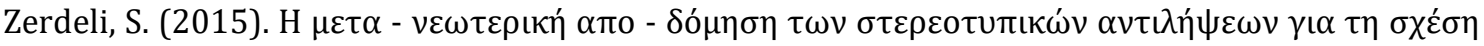

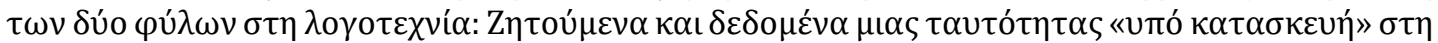

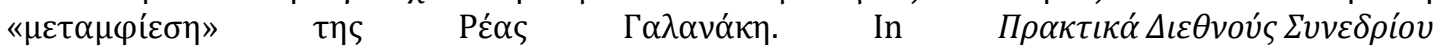

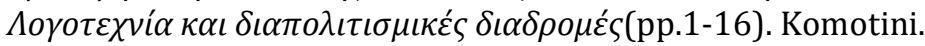



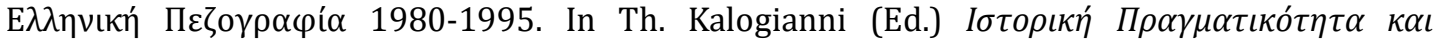

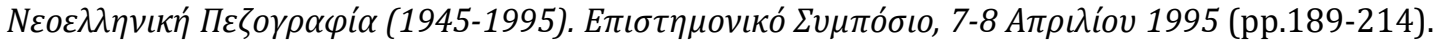

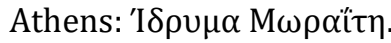

How to cite this paper:

Menti, T. \& Sideri, C. (2020). Gender in Literature. Women's Position from traditional to modern society. Journal of Literary Education, (3), pp. 93-111. doi: 10.7203/JLE.3.17340 